\title{
Bone mesenchymal stem cell therapy for ovariectomized osteoporotic rats: a systematic review and meta-analysis
}

\author{
Zhenxiong Jin ${ }^{1,2,3}$, Jinman Chen ${ }^{1,2,3}$, Bing Shu ${ }^{1,2,3}$, Yanhua Xiao ${ }^{4^{*}}$ and Dezhi Tang ${ }^{1,2,3^{*}}$ (D)
}

\begin{abstract}
Background: Previous studies have found that bone mesenchymal stem cells (BMSCs) were capable of selfreplication, multi-differentiation, and regeneration. The aim of this study was to carry out a systematic review and meta-analysis of the efficacy of BMSC therapy for ovariectomized rats.

Methods: The PubMed, Embase, Web of Science, China National Knowledge Infrastructure, VIP, and Chinese Sinomed databases were searched systematically from their initiation date to October 5, 2018. Two researchers independently screened the literatures, which used the bone mineral density (BMD), total bone volume by total tissue volume (BV/TV) (\%), and trabecular thickness/spacing (Tb/Sp) as the outcome measures.

Results: Five eligible studies were selected. In the BMSC treatment groups, the BMD values and normalized BV/TV values remarkably increased. In addition, in the BMSCs plus other treatment groups, the BMD and Tb/Sp values significantly increased.

Conclusion: This study showed that BMSCs could accelerate callus maturity, ossification and restore mechanical properties of bones in osteoporotic fractures.
\end{abstract}

Keywords: Bone mesenchymal stem cells, Fracture, Meta-analysis, Osteoporotic, Ovariectomy

\section{Background}

Osteoporosis is a systemic skeletal disease characterized by low bone mass and degradation of the bone microstructure, with consequent increases in the fragility of bone and risk of fracture [1]. A large number of complications have been discovered, which seriously threaten people's lives and health. Osteoporotic fracture is a serious complication of osteoporosis. Osteoporotic fractures occur following minimal violence or, in some cases, without trauma [2]. In the United States, about 9.9 million people suffer from osteoporosis and 43.1 million have a low bone mineral density (BMD) with an increased likelihood of fractures [1]. Moreover, in China, about 112 million people suffer from osteoporosis, and the prevalence of fractures in people aged more than 50 years of age is $26.6 \%$, with nearly one third of them due to osteoporosis [3].

\footnotetext{
* Correspondence: xyh20040701@126.com; dzt702@163.com

${ }^{4}$ Jinggangshan University, Ji'an 343009, China

${ }^{1}$ Longhua Hospital, Shanghai University of Traditional Chinese Medicine

Shanghai 200032, China

Full list of author information is available at the end of the article
}

Tissue engineering technology has been rapidly developed in the fields of bone and cartilage tissue construction, blood vessels, nerves, skin, and so on. As an important part of tissue engineering technology, stem cells have received extensive attention owing to their unique advantages. Bone marrow mesenchymal stem cells (BMSCs) represent a stem cell population that can be harvested from the bone marrow [4] and can differentiate into osteoblasts, fat, cartilage, neuron, and so on. Moreover, BMSCs have attracted much attention because of their advantages, such as easy material extraction and self-renewal [5]. Furthermore, the advantages of autologous transplantation with BMSCs include small trauma, no rejection, and few post-transplant complications [6]. It can effectively avoid bone defects and healing delay in traditional autologous bone transplants. Hence, BMSCs are widely used in cell-level clinical studies on bone and cartilage tissue. But at present, most of the treatment methods of osteoporotic fracture include mainly surgery and conservative intervention, and the

(c) The Author(s). 2019 Open Access This article is distributed under the terms of the Creative Commons Attribution 4.0 International License (http://creativecommons.org/licenses/by/4.0/), which permits unrestricted use, distribution, and reproduction in any medium, provided you give appropriate credit to the original author(s) and the source, provide a link to the Creative Commons license, and indicate if changes were made. The Creative Commons Public Domain Dedication waiver (http://creativecommons.org/publicdomain/zero/1.0/) applies to the data made available in this article, unless otherwise stated. 
severity of osteoporosis affects the occurrence, development, and prognosis of osteoporotic fractures [2]. Additionally, the perioperative treatment of osteoporotic fractures requires attention to prevent the occurrence of re-fracture [7]. Therefore, with the increase of age, the decline of physical health or other factors, new progress in innovative therapy is needed, so cell-based repair therapy has become a promising therapeutic strategy [8].

However, only a small number of the reports have been reported on the clinical application of BMSCs [9], and it is the treatment of osteoporosis, rather than osteoporotic fractures. Most of the stem cell therapy for osteoporotic fractures remains in basic research. For this we focus our attention on animal models. Ovariectomy (OVX) results in the decrease level of estrogen and is well established in investigations of osteoporotic therapies [10]. OVX induces bone loss in animals, and postmenopausal bone loss has many similar features [11], including a rapid decrease in the trabecular bone mass and an increase in bone resorption, and similar skeletal response to therapy with estrogen, bisphosphonates, tamoxifen, calcitonin. These wide-ranging similarities make ovariectomized animal models have been widely used as clinically relevant models of postmenopausal bone loss in women [12]. The ovariectomized (OVX) rat model was approved by the US Food and Drug Administration (FDA) as a preclinical model [13].

Mesenchymal stem cells have been reported beneficial to animal models of OVX [14-19]. However, in most cases, functional improvement occurs despite minimal engraftment at the site of injury, suggesting that BMSCs may have paracrine effects by secreting factors that promote regeneration without attachment [20, 21]. Although BMSC has been reported to be studied on animals, such as rats, mice, and horses. But BMSC has less research articles on animals other than rats. Therefore, the present study aimed to conduct a systematic review and meta-analysis of the efficacy of BMSCs for OVX rats. The findings can contribute to the clinical trials and treatments in the future.

\section{Methods}

\section{Literature search strategy}

Six databases, including PubMed, Embase, Web of Science, China National Knowledge Infrastructure (CNKI), VIP, and Chinese Sinomed, were systematically searched from their inception dates to October 5, 2018. The following keywords were used for the search: (Fracture AND Osteoporosis) OR (Osteoporotic Fracture) AND (Stem Cell), regardless of the language and publication date.

\section{Data extraction and quality assessment}

The studies were selected independently by two reviewers (Jin ZX and Chen JM) by screening the abstracts and full-texts according to the eligibility criteria. During the process, disagreements were resolved by consensus with a third author (Tang DZ). The studies that satisfied the inclusion and exclusion criteria were enrolled in the meta-analysis.

\section{Eligibility criteria \\ Types of studies}

Controlled studies estimating the effects of BMSCs on ovariectomized rats by in vivo administration were searched. The clinical case reports and studies having only in vitro experiments were excluded.

\section{Types of participants}

To generate osteoporotic rats, the Sprague-Dawley female rats of any age were subjected to bilateral OVX or sham operation (sham).

\section{Types of intervention}

Any type of BMSC intervention compared with placebo control was included. Placebo control included PBS, PLGA/Col microspheres, 214S, and no treatment.

\section{Types of outcome measures}

BMD was considered to be the primary outcome measure for evaluating the anti-osteoporosis efficacy by any antiosteoporosis therapy in preclinical and clinical studies. Thus, in this systematic review and meta-analysis, each study using BMD as a major result of indicators was considered. Second, the outcome indicators included total bone volume by total tissue volume (BV/TV) (\%), trabecular thickness/spacing ( $\mathrm{Tb} / \mathrm{Sp})$, and so on.

\section{Exclusion criteria}

The exclusion criteria were as follows: (1) The topics were non-primary osteoporosis and new compression fractures. (2) The types of literature were clinical trials, in vitro studies, reviews and case reports, conference articles, systematic reviews, and meta-analysis. (3) The interventions were non-BMSCs, including other stem cells, proprietary Chinese medicines, granules, and ointments. (4) The necessary data were not reported.

\section{Statistical analysis}

All the data review and meta-analysis were performed using the Review Manager 5.3 software provided by the Cochrane Collaboration. The difference between the control group and the intervention group was estimated. Continuous variable data were selected for the standardized mean difference (SMD) analysis. Each effect volume was expressed as a $95 \%$ confidence interval (CI). Heterogeneity was observed usingthe $I^{2}$ test. $I^{2} \leq 50 \%$ indicated homogeneity between the studies, which was calculated using the fixed-effects model. $I^{2}>50 \%$ indicated 
heterogeneity between studies, and a random-effects model was applied for the analysis [11].

\section{Results}

\section{Selection of studies}

The detailed flow chart of literature identification and selection process is shown in Fig. 1. A total of 1414 studies were retrieved based on the search strategy described in the Methods section, while 396 of the duplicated ones were excluded. After reviewing the titles and abstracts, 963 records were removed because the studies did not match the eligibility criteria. After reading the full text of the 55 remaining studies, 50 of them were further excluded because the 15 articles topic was non-primary osteoporosis, the 12 articles experimental animal was not the rat and the 10 articles treatment was not based on stem cells, the 12 articles in animal models are non-osteoporotic fractures. Among the remaining six studies, only one study on primary treatment used adipose-derived mesenchymal stem cells (ADSCs) [14]. Therefore, this study could not be included in this meta-analysis. Finally, five studies met the inclusion criteria and were selected for this meta-analysis.
One of the included studies was reported in the Chinese language [16], and the remaining studies were reported in English language [15, 17-19].

\section{Characteristics of the included studies}

All the five included studies used female Sprague-Dawley rats, and the number of rats used ranged from 10 to 90 . The detailed information of the background diet was not reported in the included studies. All the studies used the ovariectomized animal model. OVX results in a decrease in estrogen produced by ovaries, eventually leading to osteoporosis. Next, the fracture model of the ovariectomized rat models was established. The fracture site was femur in two studies [15, 18], tibia in one study [16], and mandibles in two studies $[17,19]$. In the included studies, the outcomes were represented as BMD, BV/TV (\%), Tb/ $\mathrm{Sp}$, or both or all three. The main features of the five studies are summarized in Table 1.

\section{Quality evaluation of the included studies}

The quality evaluation [22] of all studies included in this meta-analysis is shown in Table 2 . No studies in this

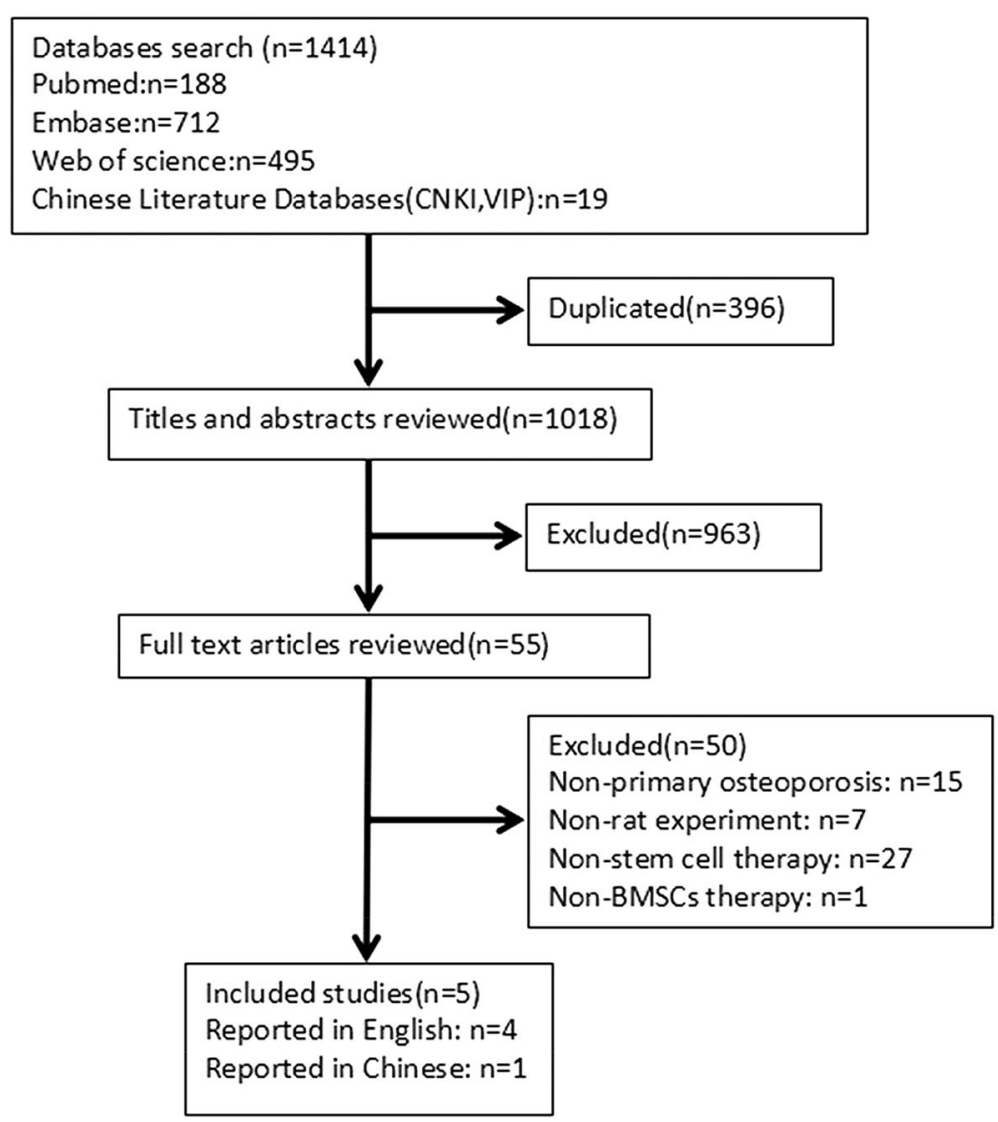

Fig. 1 Flow diagram of the literature identification and selection process. A total of 1414 studies were retrieved based on the search strategy described in the Methods section, while 396 of the duplicated ones were excluded. After reviewing the titles and abstracts, 963 records were removed because the studies did not match the eligibility criteria. After reading the full text of the 55 remaining studies, 50 of them were further excluded. Finally, five studies met the inclusion criteria and were selected for this meta-analysis 
Table 1 Characteristics of studies included in this meta-analysis

\begin{tabular}{|c|c|c|c|c|c|c|c|c|}
\hline Studies & Animals & $\begin{array}{l}\text { No. of animals } \\
(\mathrm{con} / \mathrm{v})\end{array}$ & $\begin{array}{l}\text { Fracture } \\
\text { site }\end{array}$ & $\begin{array}{l}\text { Fracture } \\
\text { model }\end{array}$ & Treatment group & $\begin{array}{l}\text { Control } \\
\text { group }\end{array}$ & $\begin{array}{l}\text { Treatment } \\
\text { duration }\end{array}$ & Outcomes \\
\hline $\begin{array}{l}\text { Yu, Zr } \\
2012 \\
{[15]}\end{array}$ & $\begin{array}{l}\text { SD rats, female, } \\
\text { 3-month-old }\end{array}$ & $8 / 8 / 8$ & femur & $\begin{array}{l}\text { OVX, } \\
\text { fracture }\end{array}$ & $\begin{array}{l}\text { BMSCs, BMSCs+PLGA/COL } \\
\text { microspheres }\end{array}$ & SHAM & 3 months & $\begin{array}{l}\text { BMD, (BV/TV), } \\
\text { (Tb.Sp) }\end{array}$ \\
\hline $\begin{array}{l}X U Z W \\
2013 \\
{[16]}\end{array}$ & $\begin{array}{l}\text { SD rats, female, } \\
(350 \pm 8.695) \mathrm{g}\end{array}$ & 18/18/18 & tibia & $\begin{array}{l}\text { OVX, } \\
\text { fracture }\end{array}$ & $\begin{array}{l}\text { BMSCs, BMSCs+Drynaria } \\
\text { fortunei extraction }\end{array}$ & Blank & $\begin{array}{l}7 / 14 / 28 / 40 \\
\text { days }\end{array}$ & BMD \\
\hline $\begin{array}{l}\text { Liu,X } \\
2016 \\
{[17]}\end{array}$ & $\begin{array}{l}\text { SD rats, female, } \\
(180-220) \mathrm{g}\end{array}$ & $12 / 12 / 12$ & mandibles & $\begin{array}{l}\text { OVX, } \\
\text { fracture }\end{array}$ & BMSCs/HA, OPG-BMSCs/HA & $\mathrm{HA}$ & 4/6/8 weeks & $\mathrm{BMD}$ \\
\hline $\begin{array}{l}\mathrm{Li}, \mathrm{KC} \\
2016 \\
{[18]}\end{array}$ & $\begin{array}{l}\text { SD rats, female, } \\
\text { 8-week-old }\end{array}$ & $8 / 8 / 6$ & femur & $\begin{array}{l}\text { OVX, } \\
\text { fracture }\end{array}$ & BMSCs, BMSCs+214S & SHAM & 2/4 weeks & $\begin{array}{l}\mathrm{BMD},(\mathrm{BV} / \mathrm{TV}), \\
(\mathrm{Tb} . \mathrm{Sp})\end{array}$ \\
\hline $\begin{array}{l}\mathrm{Xu}, \mathrm{RY} \\
2016\end{array}$ & $\begin{array}{l}\text { SD rats, female, } \\
\text { 3-month-old }\end{array}$ & $5 / 5$ & mandibles & $\begin{array}{l}\text { OVX, } \\
\text { fracture }\end{array}$ & BMSCs & SHAM & 12 weeks & (BV/TV), (Tb.Sp) \\
\hline
\end{tabular}

Abbreviations: SD Sprague-Dawley, OVX ovariectomy, BMD Bone Mineral Density, BMSCs Bone mesenchymal stem cells

meta-analysis specifically described sample-size calculations and allocation concealment, or reported exclusion criteria and outcomes of blinded assessment. Of the five studies, one reported inclusion and exclusion criteria [16], three reported randomization ${ }^{[15.16 .19]}$, and two reported potential conflicts of interest and supported funding $[15,19]$. Finally, only five published studies met the inclusion criteria. Overall, the quality evaluation of the studies was low.

\section{Forest map}

All five studies used female rats only. The experimental group had a total of 51 rats, and the control group had 49 rats. Depending on the purpose of the study and the method of intervention, two control groups were established: BMSC group and control group, and BMSCs plus other intervention groups and control group. The BMD, $\mathrm{BV} / \mathrm{TV}(\%)$, and $\mathrm{Tb} / \mathrm{Sp}$ values were compared among the groups. As each study used different time points for data measurement, the last time point was considered for analysis.
Comparison of BMD value between the BMSC group and the control group

Of the five articles, only four used BMD as the primary outcome measure [15-19]. The present meta-analysis involved 26 rats in the experimental group and 24 rats in the control group. The results showed that four studies [15-18] compared the BMSC group with the control group and they were heterogeneous. Therefore, the random-effects model was used for the analysis. The combined effect of SMD was found to be 1.04, with 95\% $\mathrm{CI}=0.03-2.06$ and $P=0.04 \quad$ (Fig. 2a). The diamond lattice did not intersect the invalid line and fell to the right of the invalid line $(P<0.05)$. Based on this analysis, the BMD values of one group were statistically significant, indicating that BMSCs increased the BMD in the ovariectomized rats.

\section{Comparison of $\mathrm{BV} / \mathrm{TV}(\%)$ value between the $\mathrm{BMSC}$ group and the control group}

Among the five studies, only three studies used the BV/ TV (\%) value as an outcome measure $[15,18,19]$. The

Table 2 Quality evaluation of the included studies

\begin{tabular}{|c|c|c|c|c|c|c|c|}
\hline Studies & $\begin{array}{l}\text { Sample-size } \\
\text { calculation }\end{array}$ & $\begin{array}{l}\text { Inclusion and } \\
\text { exclusion }\end{array}$ & Randomization & $\begin{array}{l}\text { Allocation } \\
\text { concealment }\end{array}$ & $\begin{array}{l}\text { Reporting animals } \\
\text { excluded from } \\
\text { analysis }\end{array}$ & $\begin{array}{l}\text { Blinded assessment } \\
\text { of outcomes }\end{array}$ & $\begin{array}{l}\text { Reporting potential } \\
\text { conflicts of interest } \\
\text { and study funding }\end{array}$ \\
\hline $\begin{array}{l}\text { Yu, ZR } 2012 \\
{[15]}\end{array}$ & no & no & yes & no & no & no & yes \\
\hline $\begin{array}{l}\text { XU ZW } 2013 \\
{[16]}\end{array}$ & no & yes & yes & no & no & no & no \\
\hline $\begin{array}{l}\text { Liu, X } 2016 \\
{[17]}\end{array}$ & no & no & no & no & no & no & no \\
\hline $\begin{array}{l}\mathrm{Li}, \mathrm{KC} 2016 \\
{[18]}\end{array}$ & no & no & no & no & no & no & no \\
\hline $\begin{array}{l}\text { Xu, RY } 2016 \\
{[19]}\end{array}$ & no & no & yes & no & no & no & yes \\
\hline
\end{tabular}




\begin{tabular}{|c|c|c|c|c|c|c|c|c|c|}
\hline \multirow[t]{7}{*}{$2 a$} & Study or Subgroup & \multicolumn{3}{|c|}{ Experimental } & \multicolumn{2}{|c|}{ Control } & \multicolumn{2}{|c|}{ Std. Mean Difference } & $\begin{array}{l}\text { Std. Mean Difference } \\
\text { N. Random, } 95 \% \mathrm{Cl}\end{array}$ \\
\hline & LiKC 2016 & 0.28 & 0.02 & 8 & 0.240 & $0.04 \quad 6$ & $29.2 \%$ & $1.25[0.06,2.44]$ & \\
\hline & Liu $\times 2016$ & 621 & 54 & 4 & 525 & 63 & $20.7 \%$ & $1.42[-0.27,3.12]$ & \\
\hline & Xu ZW 2013 & 3.01 & 0.93 & 10 & 2.980 & 0.89 & $35.8 \%$ & $0.03[-0.85,0.91\}$ & - \\
\hline & Yu ZR 2012 & 0.28 & 0.01 & 4 & 0.250 & 0.01 & $14.2 \%$ & $2.61[0.34,4.88]$ & \\
\hline & Total $(95 \% \mathrm{Cl})$ & & & 26 & & 24 & $100.0 \%$ & $1.04[0.03,2.06]$ & \\
\hline & \multicolumn{8}{|c|}{$\begin{array}{l}\text { Heterogeneity: Tauz }=0.55 ; \mathrm{Chi}^{2}=6.44, \mathrm{df}=3(P=0.09) ; 1^{2}=53 \% \\
\text { Test for overall effect: } Z=2.01(P=0.04)\end{array}$} & $\begin{array}{ccccc}-4 & -2 & 0 & 2 & 4 \\
\text { Favours [experimental] } & \text { Favours [control] }\end{array}$ \\
\hline \multirow{7}{*}{$2 b$} & & \multicolumn{3}{|c|}{ Experimental } & \multicolumn{2}{|c|}{ Control } & \multirow{2}{*}{\multicolumn{2}{|c|}{$\begin{array}{c}\text { Std. Mean Difference } \\
\text { Weight } \quad \text { N. Random, } 95 \% \mathrm{Cl}\end{array}$}} & \multirow{2}{*}{$\begin{array}{l}\text { Std. Mean Difference } \\
\text { N. Random, } 95 \% \mathrm{Cl}\end{array}$} \\
\hline & Study or Subgroup & Mean & SD I & Total 1 & Mean & SD Total & & & \\
\hline & LiKC 2016 & 12.22 & 1.11 & 8 & 8.671 & 1.77 & $73.6 \%$ & \multirow{3}{*}{$\begin{array}{r}2.34[0.87,3.81] \\
6.93[0.05,13.81] \\
3.24[0.62,5.87]\end{array}$} & \\
\hline & Xu R 2016 & 11.69 & 1.02 & 3 & 3.560 & 0.85 & $3.4 \%$ & & \\
\hline & Yu ZR 2012 & 6.23 & 0.3 & 4 & 5.20 & 0.25 & $23.1 \%$ & & $\longrightarrow$ \\
\hline & Total $(95 \% \mathrm{Cl})$ & & & 15 & & 13 & $100.0 \%$ & $2.70[1.44,3.96]$ & \\
\hline & \multicolumn{6}{|c|}{$\begin{array}{l}\text { Heterogeneity. } \operatorname{Tau}^{2}=0.00 ; \mathrm{Chi}^{2}=1.85, \mathrm{df}=2(\mathrm{P}=0.40) ; \mathrm{I}^{2}=0 \% \\
\text { Test for overall effect: } Z=4.20(P<0.0001)\end{array}$} & & & $\begin{array}{ccccc}-10 & -5 & 0 & 5 & 10 \\
\text { Favours [experimental] } & \text { Favours [control] }\end{array}$ \\
\hline \multirow{7}{*}{$2 c$} & & \multicolumn{3}{|c|}{ Experimental } & \multicolumn{2}{|r|}{ Control } & & Std. Mean Difference & \multirow{2}{*}{$\begin{array}{l}\text { Std. Mean Difference } \\
\text { N. Random. } 95 \% \mathrm{Cl}\end{array}$} \\
\hline & Stucty or Subgroup & Mean & SD & Total & Meal & an SD & Total Weight & IV. Random, $95 \% \mathrm{Cl}$ & \\
\hline & Li KC 2016 & 1.51 & 0.15 & 8 & 1.8 & 0.08 & $6 \quad 41.2 \%$ & $\quad-2.31[-3.77,-0.85]$ & \multirow{3}{*}{$\rightarrow-1$} \\
\hline & Xu RY 2016 & 3.12 & 0.11 & 3 & & 0.11 & $340.0 \%$ & $0.58[-1.11,2.28]$ & \\
\hline & Yu ZR 2012 & $1,769.37$ & 153.84 & 4 & $3,165.7$ & $72 \quad 153.85$ & $4 \quad 18.7 \%$ & $-7.89[-13.50,-2.29]$ & \\
\hline & \multirow{2}{*}{\multicolumn{6}{|c|}{$\begin{array}{l}\text { Total }(95 \% \mathrm{Cl}) \quad 15 \\
\text { Heterogeneity: Tau }=5.78 ; \mathrm{Chi}^{2}=11.87, \mathrm{df}=2(P=0.003) ; \mathrm{I}^{2}=83 \% \\
\text { Test for overall effect: } Z=1.36(P=0.17)\end{array}$}} & $13 \quad 100.0 \%$ & $-2.20[-5.36,0.97]$ & \\
\hline & & & & & & & & & 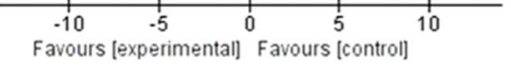 \\
\hline \multicolumn{10}{|c|}{$\begin{array}{l}\text { Fig. } 2 \text { Comparison of BMD, BV/TV (\%) and Tb/Sp value between BMSC group and control group. a Four studies comparison of BMD value and } \\
\text { they were heterogeneous. Therefore, the random-effects model was used for the analysis. The combined effect of SMD was found to be } 1.04 \text {, } \\
\text { with } 95 \% \mathrm{Cl}=0.03-2.06 \text { and } P=0.04(P<0.05) \text {. } \mathbf{b} \text { Only three studies comparison of BV/TV(\%) value and they were heterogeneous. Hence, the } \\
\text { random-effects model was used for the analysis. The combined effect of SMD was found to be } 3.90 \text {, with } 95 \% \mathrm{Cl}=2.32-5.49 \text { and } P<0.00001 \text {. } \\
\text { c Three studies used the Tb/Sp value as an outcome measure. The combined effect of SMD was found to be } 2.20 \text {, with } 95 \% \mathrm{Cl}=5.36 \text { to } 0.97 \\
\text { and } P=0.17(P>0.05)\end{array}$} \\
\hline
\end{tabular}

results of this meta-analysis showed that only three studies compared the BMSC group with the control group and they were heterogeneous. Hence, the random-effects model was used for the analysis. The combined effect of SMD was found to be 3.90, with $95 \% \mathrm{CI}=2.32-5.49$ and $P<0.00001$ (Fig. 2b). Based on this analysis, there was a statistically significant difference in BV/TV (\%) values between the two groups.

\section{Comparison of $\mathrm{Tb} / \mathrm{Sp}$ value between the BMSC group and the control group}

Of the five studies, only three studies used the $\mathrm{Tb} / \mathrm{Sp}$ value as an outcome measure ${ }^{[15.18 .19]}$. Increased $\mathrm{Tb} / \mathrm{Sp}$ suggests increased bone resorption and osteoporosis occurrence. The results of this meta-analysis showed that three studies compared the BMSC group with the control group and they were heterogeneous. Therefore, the random-effects model was used for the analysis. The combined effect of SMD was found to be -2.20 , with 95\% CI $=-5.36$ to 0.97 and $P=0.17$ (Fig. 2c). The diamond lattice did intersect the invalid line $(P>0.05)$. Based on this analysis, the $\mathrm{Tb} / \mathrm{Sp}$ values of one group were not statistically significant.

\section{Comparison of BMD value between BMSCs plus other intervention groups and control group}

The included studies were not limited to a single treatment group. The studies used BMSCs modified by PLGA/Col microspheres, 214S, and traditional Chinese medicine. The results of this meta-analysis showed that four studies [15-18] compared the BMSCs plus other intervention groups with the control group and they were heterogeneous. Hence, the random-effects model was used for the analysis. The combined effect of SMD was found to be 2.94 , with $95 \% \mathrm{CI}=0.56-5.31$ and $P=$ 0.02 (Fig. 3a). The diamond lattice did not intersect the invalid line and fell to the right of the invalid line $(P<0.05)$. Based on this analysis, the BMD values in the three groups indicated that BMSCs plus other intervention groups increased the BMD in ovariectomized rats.

\section{Comparison of BV/TV(\%) value between BMSCs plus other intervention groups and control group}

Among the five articles, two studies used the BV/TV(\%) value as an outcome measure ${ }^{[15.18]}$. The results of this meta-analysis showed that two studies compared the 


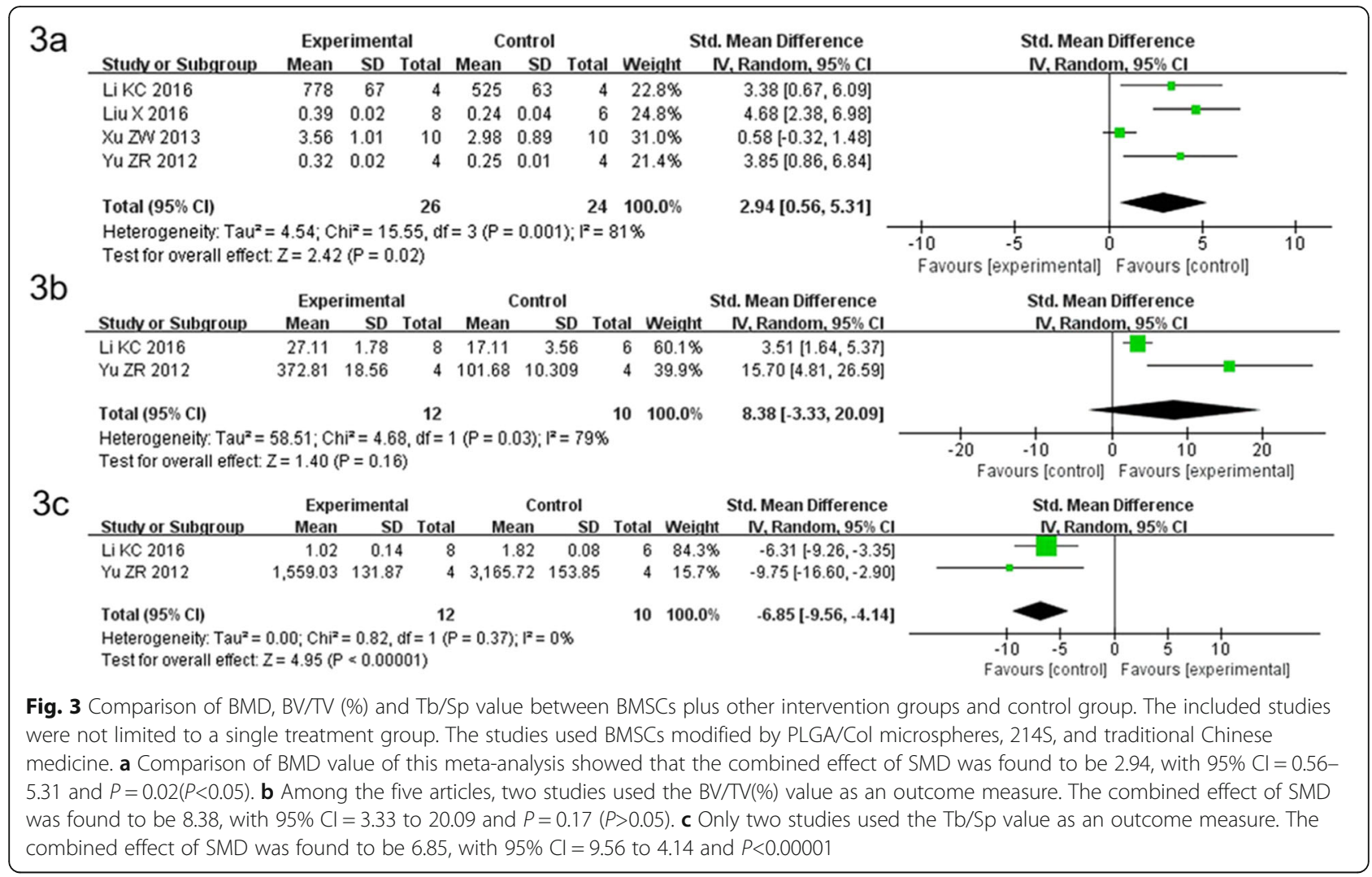

BMSCs plus other intervention groups with the control group and the studies were heterogeneous. Therefore, the random-effects model was used for the analysis. The combined effect of SMD was found to be 8.38, with $95 \%$ $\mathrm{CI}=-3.33$ to 20.09 and $P=0.17$ (Fig. $3 \mathrm{~b}$ ). The diamond lattice did intersect the invalid line $(P>0.05)$. Based on this analysis, the increase in the BV/TV (\%) value in ovariectomized rats due to BMSCs injection was not significantly different.

\section{Comparison of $\mathrm{Tb} / \mathrm{Sp}$ value between BMSCs plus other intervention groups and control group}

Of the five studies, only two studies used the $\mathrm{Tb} / \mathrm{Sp}$ value as an outcome measure ${ }^{[15.18]}$. Increased $\mathrm{Tb} / \mathrm{Sp}$ suggests that osteoporosis may occur. The results of this meta-analysis showed that three studies were heterogeneous and compared the BMSCs plus other intervention groups with the control group. Hence, the randomeffects model was used for the analysis. The combined effect of SMD was found to be -6.85 , with $95 \% \mathrm{CI}=$ - 9.56 to -4.14 and $P<0.00001$ (Fig. 3c). The diamond lattice did not intersect the invalid line and fell to the left of the invalid line. Based on this analysis, the $\mathrm{Tb} / \mathrm{Sp}$ values of the two groups indicated that BMSCs plus other intervention groups decreased the $\mathrm{Tb} / \mathrm{Sp}$ value in ovariectomized rats.

\section{Discussion}

The analyses showed that BMD values remarkably increased, indicating that BMSCs accelerated callus maturity and ossification. Moreover, the addition of other therapeutic elements to the BMSCs more dramatically increased healing. Indeed, MSC conditioned media can induce a similar or stronger osteogenic effect than transplanted cells [23]. In the BMSC monotherapy group, the $\mathrm{BV} / \mathrm{TV}$ (\%) value was significantly different, while the $\mathrm{Tb} / \mathrm{Sp}$ value was not. However, in the BMSCs plus other treatment groups, the results were exactly the opposite: the BV/TV (\%) values were not significantly different, whereas the $\mathrm{Tb} / \mathrm{Sp}$ values were. Overall, the possibility of treating the fracture site in the treatment group was significantly higher than that in the control groups, and the MSC conditioned media for bone regeneration could represent an alternative to cell-based therapies in the future.

BMSCs have the ability to differentiate into osteoblasts, fat, cartilage, neuron, and so on, and have low immunogenicity, and multi-potential differentiation. BMSCs have attracted much attention because of their advantages, such as self-renewal and multidirectional differentiation [24]. Moreover, the advantages of autologous bone marrow mesenchymal stem cell transplantation include no rejection and few post-transplant complications, it can effectively avoid bone defect and 
healing delay of traditional autologous bone transplantation [25]. Although the classical Ex vivo expanded stem cells has been validated, this requiring a lot of cultivate time before implantation [26, 27]. Several researchers have confirmed that recruitment of endogenous MSC is a viable alternative to MSC transplantation [27-29]. In some studies, BMCS has limited differentiation ability, such as Balakumaran [30] studies have shown that Telomere Biology Disorders (TBD)-BMSCs exhibited reduced clonogenicity, spontaneous differentiation into adipocytes and fibrotic cells, and increased senescence in vitro. Upon in vivo transplantation into mice, TBDBMSCs failed to form bone or support hematopoiesis, unlike normal BMSCs. Additionally, it has been reported that unmodified MSCs showed oncogenic transformation when injected into immune-compromised mice [31]. But recent studies indicates that reports of oncogenic transformation or malignant of MSCs may reflect the role of cell culture cross-contamination rather than true oncogenic transformation [32].

It is possible that the BMSCs can directly differentiate into osteoblasts in a physiological environment. However, the cytokines from transplanted cells are more likely to play an important role in bone metabolism [33]. Given that BMSC number from marrow decline with age [34]. Whereas, in the treatment of bone diseases, not only BMSCs but also ADSCs [35], muscle-derived stem cells [36], and so on, all can be induced to be divided into osteoblasts. In addition, in clinical aspects, some studies have shown that intracoronary injection of autologous BMSC can improvement in left ventricular function in patients with anterior ST-segment elevation myocardial infarction [37]. Carlos [38] et al., also reported that BMSC were transplanted into the perilesional area in five patients bearing sequels of stroke, with excellent tolerance and without complications. It has also been reported that autologous BMSCs transplantation for the treatment of breast cancer related lymphedema is effective and feasible [39]. Gunter [40] et al., found that in patients with malignant liver lesions, the combination of CD133 BMSC with portal vein embolization administration significantly increased hepatic regeneration. Women have been using stem cell technology for cosmetic indications for the past few years, and there seems to be a reason to believe that stem cells can now be used to solve more serious clinical symptoms [41].

Modern medical treatment of osteoporotic fracture is based on inhibiting bone resorption, promoting bone formation, and regulating blood calcium and blood phosphorus levels to improve pain symptoms [42]. Commonly used drugs are calcium, bisphosphonate, calcitonin, parathyroid hormone, and so on. Moreover, the drugs are combined with nonsteroidal painkillers and physical therapy [43]. Antiresorptive agents fail to adequately restore bone mass and bone quality, and daily injections of parathyroid hormone (PTH) can increase bone mass to stimulate bone formation. However, chronically elevated PTH levels cause bone resorption exceeding bone formation, ultimately resulting in osteoporosis [44] and the risk of developing osteosarcoma. Therefore, treatment options for promoting bone regeneration and reversing bone loss are currently limited. Unfortunately, researchers do not always get the results of clinical trials, and most of the results have not been published in peer-reviewed journals [45]. In short, due to the unsatisfied treatment effect, we investigate the feasibility of BMSCs to provide more clinical treatment in future.

This meta-analysis included various fracture sites (femur, tibia, and mandibles), different initiation times of treatment (1-12 weeks), different BMSC doses and sources, and various measurement standards and calculation methods. Animal information was not comprehensive, such as intervention methods, and outcome indicators, which could cause a high heterogeneity [46]. Thus, random-effects models were used for the analysis and more models of different types of fracture, unified measurement, and same treatment time are needed to verify the efficiency of BMSCs.

\section{Potential clinical value}

BMSCs have great potential for the treatment of osteoporotic fractures in clinical applications. Although a large number of studies have been conducted since the first implantation of stem cells for bone formation or bone regeneration more than 50 years ago [47], so far only a few have been used in clinical practice. According to the updated guidelines of the American College of Physicians, there are limited pharmacologic therapeutic methods to reduce the risk of osteoporosis are reduced [48]. Therefore, it is necessary to study more effective interventions for osteoporotic fractures. This study summarizes the basic research to demonstrate the therapeutic effects of BMSCs on osteoporotic fractures by promoting callus ossification, accelerating callus formation, and strengthening the healed bone. Once BMSCs are proven to be clinically effective, BMSCs have a shorter treatment time and better results. In the future, BMSCs can be used as osteoporotic fracture drugs. Although the applicable type and effective dose have not yet been identified, more rigorous animal model experiments will address this issue before clinical application.

\section{Conclusions}

In summary, as stem cell therapy may develop into a new treatment for osteoporotic fractures, more systematic studies are needed to investigate the regime, safety, 
and efficacy for fracture healing. Nowadays, the application of BMSCs in the field of orthopedics is developing rapidly. Cell-based strategies have appeared as hopeful treatment strategies when the intrinsic regenerative potential is reduced by health, age, or other factors [8]. The BMSCs could remarkably increased BMD values of osteoporotic fractures Rats. This indicating that BMSCs accelerated callus maturity, promoted ossification of the fracture site and restore the mechanical properties of the bone. Therefore, the role of BMSCs in the treatment of orthopedic diseases has become more important. Although all the research is still in the basic stage, in view of the increasing research in this field, it is believed that BMSC transplantation has a very good clinical application prospect in treating areas of bone and cartilage in the future.

\section{Abbreviations}

ADSC: Adipose-Derived Mesenchymal Stem Cells; BMD: Bone mineral density; BMSCs: Bone Marrow Mesenchymal Stem Cells; Cl: Confidence interval; FDA: Food and drug administration; OVX: Ovariectomy; SMD: Standardized mean difference

\section{Acknowledgments}

The authors would like to thank Yongjun Wang in Shanghai University of Traditional Chinese Medicine and Shuailiang Zhou in Shanghai Guanghua Hospital of Integrated Traditional Chinese and Western Medicine for help with picture making and English polishing.

\section{Authors' contributions}

$Z X J, J M C, X Y H$, and DZT participated in the conception and design of the study and preparation of the manuscript. ZXJ and JMC performed the database searches, selection of the studies, and methodological quality assessment of the studies. DZT, BS and YHX were responsible for resolving the disagreements. ZXJ and DZT completed the manuscript. All the authors read and approved the final manuscript.

\section{Funding}

This work was sponsored by research grants from the National Natural Science Foundation (81473701 and 81730107), Shanghai Scientific Research project (17401971100), the first round of a three-year action plan to promote clinical skills and clinical innovation in municipal hospitals (16CR1017A), Shanghai TCM Medical Center of Chronic Disease (2017ZZ01010), the program for innovative research of the Ministry of Science and Technology of China (2015RA4002), and "Innovation Team" development projects (IRT1270). Three Years Action to Accelerate the Development of Traditional Chinese Medicine Plan (ZY (2018-2020)-CCCX-3003).

\section{Availability of data and materials}

All data and materials are contained within the manuscript.

\section{Ethics approval and consent to participate}

Ethical approval is not necessary because it is a comment on previously published articles and does not involve the handing of any personal patient data.

\section{Consent for publication}

Not applicable.

\section{Competing interests}

Zhenxiong JIN, Jinman CHEN, Bing SHU, Yanhua XIAO and Dezhi TANG declare that they have no conflict of interest.

\section{Author details}

${ }^{1}$ Longhua Hospital, Shanghai University of Traditional Chinese Medicine, Shanghai 200032, China. ${ }^{2}$ Institute of Spine, Shanghai University of
Traditional Chinese Medicine, Shanghai 200032, China. ${ }^{3}$ Key Laboratory of Theory and Therapy of Muscles and Bones, Ministry of Education, Shanghai 200032, China. ${ }^{4}$ Jinggangshan University, Ji'an 343009, China.

Received: 17 July 2019 Accepted: 23 September 2019

Published online: 20 November 2019

\section{References}

1. Rajasekaran S, Kanna RM, Schnake KJ. Vaccaro. A R, Schroeder. G D, sadiqi. S, Oner. C. Osteoporotic thoracolumbar fractures-how are they differentclassification and treatment algorithm. J Orthop Trauma. 2017;31(4):S49-56.

2. Cosman F, de Beur SJ, LeBoff MS. Lewiecki. E M, Tanner. B, Randall. S, Lindsay. R, Clinician's guide to prevention and treatment of osteoporosis. Osteoporos Int. 2014;25(10):2359-81.

3. Zhang ZH, Liu ZH, Shi SH. A retrospective study of the incidence of osteoporosis diagnosed with $-2.5 \mathrm{SD}$ in mainland China. Chi J Osteoporos. 2015;22(1):1-7.

4. Elsafadi M, Manikandan M, Atteya M, Hashmi JA, lqbal Z, Aldahmash A, Alfayez M, Kassem M, Mahmood A. Characterization of cellular and molecular heterogeneity of bone marrow stromal cells. Stem Cells Int. 2016; 2016:9378081

5. Kuznetsov SA, Riminucci M, Ziran N, Tsutsui TW, Corsi A, Calvi L, Kronenberg HM, Schipani E, Robey PG, Bianco P. The interplay of osteogenesis and hematopoiesis: expression of a constitutively active PTH/PTHrP receptor in osteogenic cells perturbs the establishment of hematopoiesis in bone and of skeletal stem cells in the bone marrow. J Cell Biol. 2004;167(6):1113-22.

6. Hu CF. Analysis of clinical efficacy of autologous bone marrow stem cell transplantation therapy in 106 patients with severe lower limb ischemia. J Hainan Med Coll. 2013;19(3):365-6 370.

7. ZHANG XY, ZHAO G, SHANG W. Perioperative drug therapy for osteoporotic fractures. Chin J Osteoporos. 2014;20(02):214-8.

8. Bianco P, Cao X, Frenette PS, Mao JJ, Robey PG, Simmons PJ, Wang CY. The meaning, the sense and the significance: translating the science of mesenchymal stem cells into medicine. Nat Med. 2013;19(1):35-42.

9. Lozano-Rivas N, Linares LF, Marras-Fernandez-Cid C, GarciaHernandez AM, Algueró MDC, Iniesta F, Sanchez-Salinas D, LópezLucas MD, Rodriguez-Valiente M, Cabañas V, García-Bernal D, Molina MDM, Lopez S, Ramirez-Tovar F, Sará JER, García B, Blanquer M, Fernandez-Delgado JAO, Espinosa M, Zamarro J, Becerra-Ratia J, Peris JL, López-Exposito I, Bafalliu JA, Ruiz-Espejo F. Clinical trial of intravenous infusion offucosylated bone marrow mesenchymal stem cells in patients with osteoporosis. Ann Rheum Dis. 2018. https://doi.org/10.1136/ annrheumdis-2018-eular.6625 (Scientific Abstracts).

10. Mathavan N, Turunen M, Tagil M, et al. Characterising bone material composition and structure in the Ovariectomized (OVX) rat model of osteoporosis. J Calcif Tissue Int. 2015;97(2):134-44.

11. Kalu DN. The ovariectomized rat model of postmenopausal bone loss. Bone Miner. 1991;15(3):175-91 Epub 1991/12/01. PMID: 1773131.

12. Chen L, Yang L, Yao M, Cui XJ, Xue CC, Wang YJ, Shu B. Biomechanical characteristics of osteoporotic fracture healing in Ovariectomized rats: a systematic review. PLoS One. 2016;11(4):e0153120.

13. Johnston $\mathrm{BD}$, Ward WE. The Ovariectomized rat as a model for studying alveolar bone loss in postmenopausal women. J BioMed Res Int. 2015:2015:1-12.

14. Tang D, Ju C, Liu Y, Xu F, Wang Z, Wang D. Therapeutic effect of icariin combined with stem cells on postmenopausal osteoporosis in rats. J Bone Miner Metab. 2018:36(2):180-8.

15. Yu Z, Zhu T, Li C, Shi X, Liu X, Yang X, Sun H. Improvement of intertrochanteric bone quality in osteoporotic female rats after injection of polylactic acid-polyglycolic acid copolymer/collagen type I microspheres combined with bone mesenchymal stem cells. Int Orthop. 2012;36(10):2163-71.

16. XU ZW, Liu G. Effects of BMSCs transplantation on the healing of osteoporotic fracture in model rats. Shandong J Tradit Chin Med. 2013;(9):51-3.

17. Liu X, Bao C, Xu HHK, Pan J, Hu J, Wang P, Luo E. Osteoprotegerin genemodified BMSCs with hydroxyapatite scaffold for treating critical-sized mandibular defects in ovariectomized osteoporotic rats. Acta Biomater. 2016:42:378-88

18. Li KC, Chang YH, Yeh CL, Hu YC. Healing of osteoporotic bone defects by baculovirus-engineered bone marrow-derived MSCs expressing MicroRNA sponges. Biomaterials. 2016;74:155-66.

19. Xu R, Fu Z, Liu X, Xiao T, Zhang P, Du Y, Yuan $H$, Cheng J, Jiang $H$. Transplantation of osteoporotic bone marrow stromal cells rejuvenated by 
the overexpression of SATB2 prevents alveolar bone loss in ovariectomized rats. Exp Gerontol. 2016:84:71-9.

20. Lee RH, Pulin AA, Seo MJ. Intravenous hMSCs improve myocardialinfarction in mice because cells embolized in lung are activated tosecrete the antiinflammatory protein TSG-6 cell. Stem Cell. 2009;5:54-63.

21. Ripperda CM, Maldonado PA, Acevedo JF, Keller PW, Akgul Y, Shelton JM, Word RA. Vaginal estrogen: a dual-edged sword in postoperative healing of the vaginal wall. Menopause. 2017;24(7):838.

22. Stroke Therapy Academic Industry Roundtable (STAIR). Recommendations for standards regarding preclinical neuroprotective and restorative drug development. Stroke. 1999;30(12):2752-8.

23. Osugi M, Katagiri W, Yoshimi R, et al. Conditioned media from mesenchymal stem cells enhanced bone regeneration in rat Calvarial bone defects [J]. Tissue Eng A. 2012;18(13-14):1479-89.

24. Fahy N, Alini M, Stoddart MJ. Mechanical stimulation of mesenchymal stem cells: implications for cartilage tissue engineering. Orthop Res. 2018;36(1):52-63.

25. Hu CF. Autologous bone marrow stem cell transplantation therapy clinical analysis of 106 patients with severe lower limb ischemia patients. J Hainan Med Univ. 2013;19(3):365-366,370.

26. Ko IK, Lee SJ, Atala A, et al. In situ tissue regeneration through host stem cell recruitment [J]. Exp Mol Med. 2013;45(11):e57.

27. WSV B. In situ tissue regeneration: Chemoattractants for endogenous stem cell recruitment [J]. Tissue Eng Part B Rev. 2014;20(1):28-39.

28. Chen FM, Wu LA, Zhang M, et al. Homing of endogenous stem/progenitor cells for in situ tissue regeneration: promises, strategies, and translational perspectives. J Biomaterials. 2011;32(12):3189-209.

29. Anitua E, Sánchez M, Orive G. Potential of endogenous regenerative technology forin situregenerative medicine [J]. Adv Drug Deliv Rev. 2010; 62(7):741-52.

30. Balakumaran A, Mishra PJ, Pawelczyk E, Yoshizawa S, Sworder BJ, Cherman N, Kuznetsov SA, Bianco P, Giri N, Savage SA, Merlino G, Dumitriu B, Dunbar CE, Young NS, Alter BP, Robey PG. Bone marrow skeletal stem/progenitor cell defects in dyskeratosiscongenita and telomere biology disorders. Blood. 2015;125(5):793.

31. Vilalta M, Dégano IR, Bagó J, Gould D, Santos M, García-Arranz M, Ayats R, Fuster C, Chernajovsky Y, García-Olmo D, Rubio N, Blanco J. Biodistribution, Long-term Survival, and Safety of Human Adipose Tissue-derived Mesenchymal Stem Cells Transplanted in Nude Mice by High Sensitivity Non-invasive Bioluminescence Imaging. Stem Cells Dev. 2008;17(5):993-1004

32. Torsvik A, Røsland GV, Svendsen A, Molven A, Immervoll H, McCormack E, Lønning PE, Primon M, Sobala E, Tonn JC, Goldbrunner R, Schichor C, Mysliwietz J, Lah TT, Motaln H, Knappskog S, Bjerkvig R. Spontaneous malignant transformation of human mesenchymal stem cells reflects crosscontamination : putting the research field on track - letter. Cancer Res. 2010; 70(15):6393.

33. Uejima S, Okada K, Kagami H, Taguchi A, Ueda M. Bone marrow stromal cell therapy improves femoral bone mineral density and mechanical strength in ovariectomized rats. Cytotherapy. 2008;10(5):479-89.

34. Caplan Al. Adult mesenchymal stem cells for tissue engineering versus regenerative medicine, J. J Cell Physiol. 2007;213(2):341-7.

35. Huang DG, Gao YH, Wang SL, Ivanovic Z. A new method for efficient amplification of human adipose-derived mesenchymal stem cells in vitro. J Hainan Med Univ. 2017;28(10):1617-20.

36. Xiang L, Liang C, Zhen-Yong K, Liang-Jun Y, Zhong-Liang D. BMP9-induced osteogenetic differentiation and bone formation of muscle-derived stem cells. J Biomed Biotechnol. 2012;2012(1):111-3.

37. Hyun KS, Hyun CJ, Ho LY, Lee JH, Kim SS, Kim MY, Lee MG, Kang WY, Lee KS, Ahn YK, Jeong MH, Kim HS. Improvement in left ventricular function with intracoronary mesenchymal stem cell therapy in a patient with Anterior Wall ST-segment elevation myocardial infarction. Cardiovasc Drugs Ther. 2018;32(4):329-38.

38. Monteagudo CS, Ramírez PH, González LA, García-Maeso I, de la CuétaraBernal K, Castillo-Díaz L, Bringas-Vega ML, Martínez-Aching G, MoralesChacón LM, Báez-Martín MM, Sánchez-Catasús C, Carballo-Barreda M, Rodríguez-Rojas R, Gómez-Fernández L, Alberti-Amador E, Macías-Abraham C, Balea ED, Rosales LC, Del Valle Pérez L, Ferrer BB, González RM, Bergado JA. Autologous bone marrow stem cell neurotransplantation in stroke patients. An open study. Restor Neurol Neurosci. 2009;27(3):151.

39. Hou C, Wu X, Jin X. Autologous Bone Marrow Stromal Cells Transplantation for the Treatment of Secondary Arm Lymphedema: A Prospective
Controlled Study in Patients with Breast Cancer Related Lymphedema. Jpn J Clin Oncol. 2008;38(10):670-4.

40. Fürst G, Schulte am Esch J, Poll LW, Hosch SB, Fritz LB, Klein M, Godehardt E, Krieg A, Wecker B, Stoldt V, Stockschläder M, Eisenberger CF, Mödder U, Knoefel WT. Portal vein embolization and autologous CD133+ bone marrow stem cells for liver regeneration: initial experience. Radiology. 2007;243(1):171-9.

41. Caplan Al. Adult mesenchymal stem cells and women's health. Menopause. 2015;22(2):131-5.

42. Compston JE, McClung MR, Leslie WD. Osteoporosis. Lancet J. 2019; 393(10169):364-76.

43. Russow G, Jahn D, Appelt J, Märdian S, Tsitsilonis S, Keller J. Anabolic Therapies in Osteoporosis and Bone Regeneration. Int J Mol Sci. 2018;20(1): pii: E83.

44. Wojda SJ, Donahue SW. Parathyroid hormone for bone regeneration. J Orthop Res. 2018;36(10):2586-94.

45. Ho-Shui-Ling A, Bolander J, Rustom LE, Johnson AW, Luyten FP, Picart C. Bone regeneration strategies: engineered scaffolds, bioactive molecules and stem cells current stage and future perspectives. Biomaterials. 2018;180:143-62.

46. Chang JL, Wang WY, Li YM, Hu SP, Yao M, Cui XJ, Zhi WL, Shi Q, Wang YJ, Yang YP. Chinese herbal medicine for osteosarcoma in the mouse: a systematic review and meta-analysis. Chin J Integr Med. 2019;25(5):370-7.

47. Friedenstein AJ, Piatetzky S, Petrakova KV. Osteogenesis in transplants of bone marrowcells. Embryol Exp Morphol. 1966;16:381-90.

48. Qaseem A, Forciea MA, McLean RM, Denberg TD. Treatment of low bone density or osteoporosis to prevent fractures in men and women: a clinical practice guideline update from the American College of Physicians. Ann Intern Med. 2017;166(11):818-39.

\section{Publisher's Note}

Springer Nature remains neutral with regard to jurisdictional claims in published maps and institutional affiliations.
Ready to submit your research? Choose BMC and benefit from:

- fast, convenient online submission

- thorough peer review by experienced researchers in your field

- rapid publication on acceptance

- support for research data, including large and complex data types

- gold Open Access which fosters wider collaboration and increased citations

- maximum visibility for your research: over $100 \mathrm{M}$ website views per year

At $\mathrm{BMC}$, research is always in progress.

Learn more biomedcentral.com/submissions 